Loading

The Journal of the Canadian Game Studies Association

\title{
Game Design and Affect: How Games Move Us as a Catalyst for Explorations in Game Studies
}

\section{Christopher Hugelmann}

Volume 12, Number 19, Winter-Spring 2019

URI: https://id.erudit.org/iderudit/1058321ar

DOI: https://doi.org/10.7202/1058321ar

See table of contents

Publisher(s)

Canadian Game Studies Association

ISSN

1923-2691 (digital)

Explore this journal

Cite this review

Hugelmann, C. (2019). Review of [Game Design and Affect: How Games Move Us as a Catalyst for Explorations in Game Studies]. Loading, 12(19).

https://doi.org/10.7202/1058321ar

\section{Article abstract}

How Games Move Us: Emotion By Design is an introduction to the ways in which digital games and game studies are slowly encroaching on other territory; in this case, Isbister looks at the intersection of psychology, kinesthetics, design and games and how new notions from these fields alter our understanding of games as a whole. The book is aimed at changing how people talk about and understand digital games, not only as a technical object but as a social medium. Isbister readily accomplishes her goal of highlighting the ways that people can affect and are affected by games, though at times, the book struggles with its strong reliance on examples and dated references to the field of game studies and psychology.
This document is protected by copyright law. Use of the services of Erudit (including reproduction) is subject to its terms and conditions, which can be viewed online.

https://apropos.erudit.org/en/users/policy-on-use 


\title{
Game Design and Affect: How Games Move Us as a Catalyst for Explorations in Game Studies
}

\author{
Christopher Hugelmann \\ Ryerson University \\ chugelmann@ryerson.ca
}

Katherine Isbister, How Games Move Us: Emotion by Design. Cambridge, Mass: The MIT Press, 2016, 167 pp., \$24.95 hardcover, \$15.95 paper (978-0-2625-3445-1)

How Games Move Us: Emotion By Design is an introduction to the ways in which digital games and game studies are slowly encroaching on other territory; in this case, Isbister looks at the intersection of psychology, kinesthetics, design and games and how new notions from these fields alter our understanding of games as a whole. The book is aimed at changing how people talk about and understand digital games, not only as a technical object but as a social medium. This work is vital and timely, given the large space that games now occupy in our daily lives, from console gaming to smartphone gaming. Isbister positions herself as a tour guide of sorts; the book is a showcase of how games offer an opportunity for emotions like empathy to be explored and experienced digitally. In this way, Isbister turns the usual narrative of isolated, melancholy gamers on its head and instead offers an exploration of how games allow for positive, pro-social emotions and behaviour to flourish. Isbister readily accomplishes her goal of highlighting the ways that people can affect and are affected by games, though at times, the book struggles with its strong reliance on examples and dated references to the field of game studies and psychology.

Currently, Isbister is a professor in the Department of Computational Media at the University of Southern California, Santa Cruz. She is also a faculty member associated with the Center for Games and Playable Media. She has written one other book: Better Game Characters by Design: A Psychological Approach and was an editor - along with Noah Schaffer - of Game Usability: Advice from the Experts for Advancing the Player Experience. Thus, Isbister's background in usability and interaction lends itself readily to an application towards digital games as an interactive media.

Despite the burgeoning field of game studies, not much attention has been paid to emotions, and work that is being done is not shared "in a way that makes sense to people who don't devote all their waking hours to studying games" (Isbister, 2016, p. xvi). As such, Isbister sets out to make a claim for emotions in game studies in a way that is comprehensible to all readers. Her introduction outlines the necessity of this work, given the "watershed moment" (p. xv) that games are experiencing, and relays her fears of the conversation surrounding digital games not catching up with the work being done. In Chapter 1, Isbister outlines two elements of games that distinguish games as a media from other entertainment sources: the ability to enact meaningful choices, and the state of flow - utilizing Csikszentmihalyi (1997). The strong usage of 
psychological studies as examples highlights choice and flow as influential, as well as the importance of Non-Playable Characters (NPCs) and relationship-building in games. Chapter 2 focuses on sociability and social play between players, discussing role-playing and "coordinated action [...] lead[ing] to greater feelings of connectedness" (Isbister, 2016, p. 45). Chapter 3 discusses the implementation of movement and interpersonal dynamics, while Chapter 4 explores the everyday sort of actions that happen in multiplayer networked games such as massively-multiplayer online role-playing games (MMORPGs). Isbister also posits that "extended play is far more meaningful when embedded in understandable human social frameworks" (p. 123). Isbister's conclusion circles back to her original premise that games inherently possess a different emotional character than other media, and it is this "palette of emotional experiences" (p. 4) that needs to be explored in the future.

Isbister's analysis is compelling and engaging and certainly adds something new to the field of game studies, which has recently seen a shift away from ideas like gameplay mechanics (see Consalvo, 2007) or the design of games (see Swink, 2009) in favour of affect and emotions (see McGonigal, 2011; Madigan, 2016). Despite its addition to the field, the depth of critical analysis seems somewhat lacking. While proposing something as interesting as adding grounded cognition theory into game studies, Isbister (2016) offers only one scholarly source, which results in a two-page showcase of two games - namely Black and White: Creature Isle (Lionhead Studios, 2002) and Train (Brenda Brathwaite Romero, 2009) - that are tangentially related to the aforementioned theory. Isbister may be anticipating that the illustrative nature of these examples will bolster the ideas presented, but it is lackluster when she positions this book as sharing what she has "been researching for many years" (p. xvii).

Ultimately, Isbister provides a layperson's introduction to her field of research, focusing in on how games create emotions, which is the purpose of the "Playful Thinking Series" this book is published within. The editors - Jesper Juul, Geoffrey Long, and William Uricchio - make the case that the series is meant to be a "series of short, readable and argumentative books" with an audience ranging from "academics" to "curious players" (p. ix). Despite the criticisms outlined above, Isbister accomplishes exactly what the "Playful Thinking Series" set out to do with How Games Move Us: Emotion By Design. That is, to put a book in the hands of the public concerning emerging topics in digital games that they can understand and take something away from it. Though it could be argued there is a strong reliance on examples and anecdotes to formulate her ideas, the examples she uses are a useful launching point for those interested in emotions in games studies. Her review of meaningful choices and flow in digital game design is important for setting the stage for her expansion in the game studies field, which readily opens up the conversation in terms of social play, movement, and networked play. Though Emotion by Design: How Games Move Us does not inherently claim to be a book about game design, the techniques that Isbister describes do lend themselves to this field of inquiry. Isbister's strength lies in her ability to convey ideas simply, and her writing is at its best within already-sanctified ideas in games studies such as flow and its accompanying psychological research. This book may lead to a "more nuanced and detailed appreciation for how games move players emotionally" (p. 132) as Isbister reflects on in the concluding pages, but it truly stands as a superb introduction to games studies and research into emotions within games. 


\section{References}

Consalvo, M. (2007). Cheating: Gaining advantage in videogames. Cambridge, Mass: MIT Press.

Csikszentmihalyi, M. (1997). Finding flow: The psychology of engagement with everyday life. New York: Basic Books.

Isbister, K. (2006). Better game characters by design: A psychological approach. San Francisco, CA: Elsevier.

Isbister, K. (2016). How games move us: Emotion by design. Cambridge, MA: MIT Press.

Isbister, K., \& Schaffer, N. (2008). Game usability: Advice from the experts for advancing the player experience. San Francisco, CA: Morgan Kaufmann.

Lionhead Studios. (2002). Black and White: Creature Isle [video game]. Electronic Arts.

Madigan, J. (2016). Getting gamers: The psychology of video games and their impact on the people who play them. Lanham, MD: Rowman \& Littlefield.

McGonigal, J. (2011). Reality is broken: Why games make us better and how they can change the world. New York, NY: Penguin Press.

Romero, B. B. (2009). Train [Board game].

Swink, S. (2009). Game feel: A game designer's guide to virtual sensation. Boston, MA: Morgan Kaufmann. 